\title{
Convalescent (Immune) Plasma Followed by Intravenous Immunoglobulin Infusion in an Adolescent with Severe COVID-19
}

\author{
Şiddetli COVID-19'lu Ergende Konvalesan (İmmün) Plazmayı İzleyen İntravenöz İmmünoglobülin \\ İnfüzyonu
}

\author{
Öner ÖZDEMİR ${ }^{1}$ \\ (1) 0000-0002-5338-9561 \\ Bahri ELMAS ${ }^{2}$ \\ (D) 0000-0001-9034-6109 \\ Mehmet Cemal DÖNMEZ ${ }^{2}$ \\ (1) 0000-0003-3939-2235 \\ Hüseyin SÜTLÜOĞLU ${ }^{3}$ \\ (D) 0000-0003-2868-8743
}

\begin{abstract}
${ }^{1}$ Department of Pediatric Allergy and Immunology, Sakarya University Faculty of Medicine, Sakarya, Turkey ${ }^{2}$ Department of Pediatrics, Sakarya University Training and Research Hospital, Sakarya, Turkey
\end{abstract}

${ }^{3}$ Medical Doctor, Sakarya University Faculty of Medicine, Sakarya, Turkey

Corresponding Author

Sorumlu Yazar

Öner ÖZDEMIR

ozdemir_oner@hotmail.com

Received / Geliş Tarihi : 17.05.2021 Accepted / Kabul Tarihi : 12.07.2021 Available Online /

Çevrimiçi Yayın Tarihi : 26.07.2021

\begin{abstract}
Coronavirus disease 2019 (COVID-19) pandemic has drawn attention over old immunotherapeutic agents such as convalescent (immune) plasma (CIP). Here, an adolescent with severe COVID-19 case requiring CIP and intravenous immunoglobulin (IVIG) treatments is described. A 17-year-old male patient was brought to the emergency room with complaints of fever, fatigue, and severe cough. Two doses of CIP were infused to the patient because of the increase in persisting fever, dyspnea, and acute phase reactant levels after the third day of routine protocol treatment. IVIG therapy was begun for 2 days at a dose of $1 \mathrm{~g} / \mathrm{kg} / \mathrm{day}$ due to resurgence in acute phase reactants and progressing radiological findings following CIP transfusion. Our patient avoided mechanical ventilation and showed immediate clinical and radiological improvement with CIP transfusion followed by IVIG therapy. Timely initiation of CIP treatment followed by IVIG prevented the disease from worsening and helped to reduce the requirement for mechanical ventilation.

Keywords: Convalescent (immune) plasma; COVID-19; intravenous immunoglobulin.
\end{abstract}

ÖZ

Koronavirüs hastalığı 2019 (coronavirus disease 2019, COVID-19) pandemisi konvalesan (immün) plazma (CIP) gibi eski immünoterapötik ajanların üzerine dikkati çekmiştir. Burada, CIP ve intravenöz immünoglobulin (IVIG) tedavisi gerektiren şiddetli COVID-19 hastalığı olan bir adolesan olgu sunulmaktadır. 17 yaşında erkek hasta ateş, yorgunluk ve şiddetli öksürük yakınmalarıyla acil servise getirildi. Hastaya rutin protokol tedavisinin üçüncü gününden sonra devam eden ateş, nefes darlığı ve akut faz reaktan düzeylerindeki artış nedeniyle iki doz CIP infüzyonu uygulandı. CIP transfüzyonu sonrası akut faz reaktanlarında yeniden artış ve ilerleyen radyolojik bulgular nedeniyle 2 gün süreyle $1 \mathrm{~g} / \mathrm{kg} /$ gün dozunda IVIG tedavisine başlandı. Hastamız CIP transfüzyonunu takiben IVIG tedavisiyle hemen klinik ve radyolojik iyileşme gösterdi ve mekanik vantilatör uygulamasından kurtuldu. CIP tedavisinin zamanında başlatılması ve ardından verilen IVIG, hastalığın kötüleşmesini önlemiş ve mekanik ventilasyon ihtiyacının azaltılmasına yardımcı olmuştur.

Anahtar kelimeler: Konvalesan (immün) plazma; COVID-19; intravenöz immunoglobulin.

\section{INTRODUCTION}

The immune response is vital for the control and improvement of viral infections. The literature reports different immunotherapeutic modalities including convalescent (immune) plasma (CIP) therapy and intravenous immunoglobulin (IVIG) and their beneficial outcomes in coronavirus disease 2019 (COVID-19) (1-7). Here, an adolescent case with severe COVID-19 disease requiring CIP and IVIG treatments to recover is discussed under the light of current literature. 


\section{CASE REPORT}

A 17-year-old male patient without any known illness was brought to the emergency room with complaints of fever, fatigue, and severe cough. His complaints had started 22 days before hospitalization, with insistent weakness, sore throat, runny nose, and mild cough. No pneumonia signs were detected in computed tomography (CT) one week after symptoms onset, and symptomatic treatment was given. On the $11^{\text {th }}$ day of his complaints, he represented with persistent nasal discharge, paroxysmal and severe cough, causing dyspnea; and antibiotherapy and 5-day methylprednisolone $(1 \mathrm{mg} / \mathrm{kg} /$ day $)$ were given. Two days later, the patient had increased weakness, severe cough with phlegm, and a persistent fever of $38-39^{\circ} \mathrm{C}$ despite acetaminophen intake. He was hospitalized to our general pediatric wards due to positive (severe acute respiratory syndrome coronavirus 2 (SARS-CoV-2) polymerase chain reaction (PCR) test and nonspecific pneumonia findings (diffuse nodular consolidations in both hemithorax) in thorax CT scan (Figure 1a, 1b).

At the admission his general condition was moderate; physical examinations demonstrated decreased lung sounds and diffuse crackles on both lungs. Mild lymphopenia $(1290 / \mu \mathrm{L})$, transient elevation of AST/ALT, high CRP $(115, \mathrm{n}:<5) \mathrm{mg} / \mathrm{L}$, and normal D-dimer were detected. The patient was started on ceftriaxone $4 \mathrm{~g} / \mathrm{bid}$ (50 $\mathrm{mg} / \mathrm{kg} / \mathrm{day})$ and hydroxychloroquine $400 \mathrm{mg} / \mathrm{bid}(5 \mathrm{mg} / \mathrm{kg}$ base/day) for 5 days.

On the third day of admission, subcostal-intercostal retractions and dyspnea began with exercise and talking. Lymphopenia deepened as $945 / \mu \mathrm{L}, \mathrm{CRP}$ increased up to $147 \mathrm{mg} / \mathrm{L}$. The postero-anterior chest $\mathrm{x}$-ray showed an increase in bilateral lung infiltration areas. Hydroxychloroquine therapy was changed to favipiravir $3200 \mathrm{mg} /$ day at two doses of loading and $1200 \mathrm{mg} /$ day for maintenance in a total of 5 days. Vancomycin $2 \mathrm{~g} /$ day and azithromycin $250 \mathrm{mg} /$ day were added. High flow nasal cannula (HFNC) oxygen therapy was initiated after being transferred to pediatric intensive care unit.

On the fourth day of his admission, increase in dyspnea was observed with exercise and talking. Fibrinogen was 462 (n: 202-430) mg/dl, ferritin: 1036 (n: 4.6-204) ng/mL and IL6: 21.95 (n: 0-7) pg/mL were elevated (Table 1). First dose of CIP was administered because of the increase in persisting fever, dyspnea, and acute phase reactant levels. Enoxaparin $4000 \mathrm{IU} / \mathrm{day}$ was added into his treatment.

On the fifth day, postero-anterior x-ray showed increased infiltration in the right lung. On the sixth day, pathologic lung sounds in the right were increased, considered as consolidation. A second dose of CIP was administered, because the consolidation developed in the right lung and the acute phase reactants were still above the normal, despite a decreasing trend.

On the seventh day, pathologic right lung sounds were decreased and there were crackles in the left lung. Blood gas analysis showed high lactate level $(3.4 \mathrm{mmol} / \mathrm{L})$. The thorax CT demonstrated an increase of infiltration extending through to upper segments (Figure 2a, 2b). Since resurgence in acute phase reactants and progressing radiological findings, IVIG therapy was begun for 2 days at a dose of $1 \mathrm{~g} / \mathrm{kg} /$ day.

On the eighth day, the patient stated significant regression in his exercise dyspnea and cough. Blood gas analysis showed mild respiratory alkalosis $\left(\mathrm{pH}: 7.48, \mathrm{pCO}_{2}: 32.8\right.$ $\mathrm{mmHg}$ ). On the ninth day, following the second dose of IVIG, auscultation findings of both lungs were significantly lessened, the patient started to be able to eat comfortably, and activity increase was observed. The HFNC oxygen flow was started to reduce. Chest X-rays progressively demonstrated diffuse consolidation regions containing air bronchograms in both lungs at the $8^{\text {th }}$ thru $9^{\text {th }}$ day of admission (Figure 3a, 3b). On the tenth day, the pulmonary auscultation findings turned back to normal. Chest X-ray showed partial resolution of consolidation regions in both lungs (Figure 3c). On the eleventh day, he was transferred to general pediatric wards. He was discharged on $14^{\text {th }}$ day and ceftriaxone was discontinued.
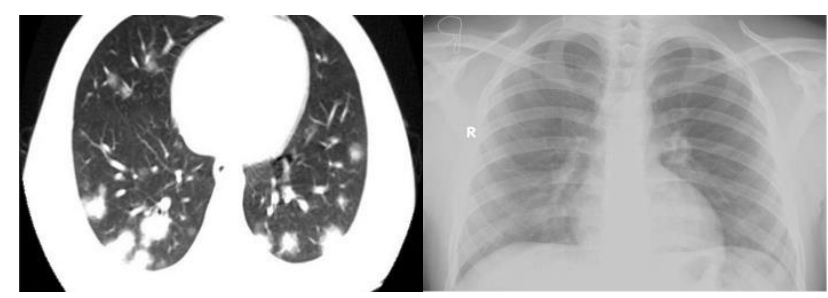

Figure 1a. Although CT shows diffuse nodular consolidations in both hemithorax (nonspesific findings for COVID-19 pneumonia); 1b. chest X-ray seems to be roughly normal at the day of hospitalization
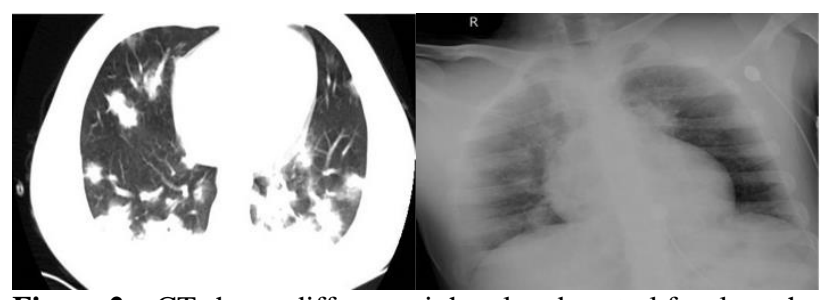

Figure 2a. CT shows diffuse peripheral and central focal patchy ground-glass opacities and air bronchograms in both hemithorax (specific for COVID-19 pneumonia) at the $7^{\text {th }}$ day of hospitalization; 2b. Chest X-ray also demonstrates diffuse consolidation regions containing air bronchograms at the same day of admission

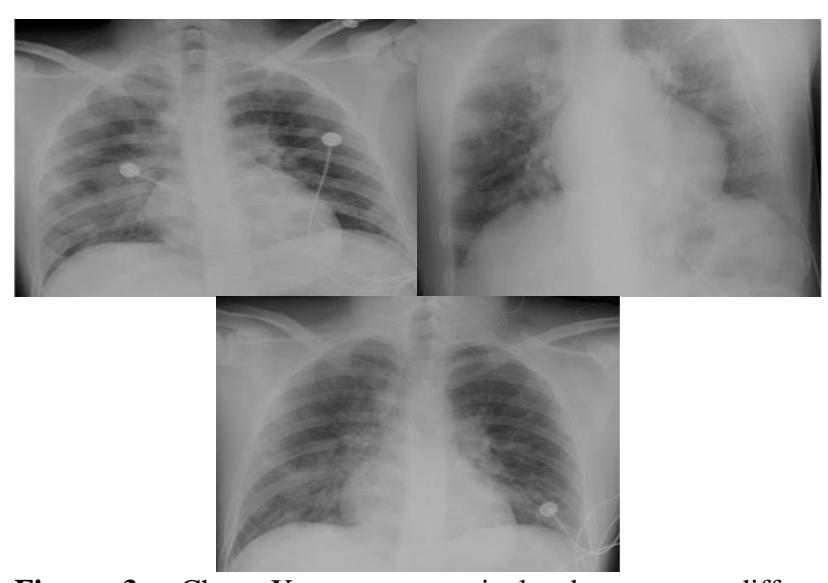

Figure 3a. Chest X-rays progressively demonstrate diffuse consolidation regions containing air bronchograms in both lungs at the $8^{\text {th }}$ and $\mathbf{3 b}$. $9^{\text {th }}$ day of admission; $3 \mathbf{c}$. it shows partial resolution of consolidation regions in both lungs at the $10^{\text {th }}$ day of admission 
Table 1. Change in acute phase reactants of our patient during hospitalization

\begin{tabular}{|c|c|c|c|c|c|c|c|c|c|}
\hline & Day 1 & Day 3 & Day 4 & Day 5 & Day 6 & Day 7 & Day 8 & Day 9 & Day 10 \\
\hline $\mathbf{W B C}(/ \mu \mathrm{L})$ & 13300 & 5130 & 4800 & 5520 & 5170 & 5880 & 7430 & 5540 & 4640 \\
\hline Neutrophil $(/ \mu \mathrm{L})$ & 10800 & 3690 & 3280 & 3210 & 3510 & 3270 & 5550 & 3740 & 2900 \\
\hline Lymphocyte $(/ \mu \mathrm{L})$ & 1290 & 945 & 1080 & 1580 & 1230 & 2030 & 1260 & 1290 & 1170 \\
\hline CRP (mg/L, n: <5) & 115 & 147 & 95 & 65 & 58 & 48 & 87 & 72 & 48 \\
\hline Procalcitonin $(\mathrm{ng} / \mathrm{mL}, \mathrm{n}:<0.5)$ & & & 0.33 & 0.19 & 0.15 & 0.11 & 0.10 & 0.06 & 0.04 \\
\hline D-dimer ( $\mu \mathrm{gFEU} / \mathrm{L}, \mathrm{n}:<500)$ & 154 & 266 & 494 & 327 & 316 & 931 & 434 & 716 & 2630 \\
\hline Fibrinogen (mg/dL, n: 202-430) & & & 462 & 462 & 443 & 434 & 614 & 417 & 380 \\
\hline Ferritin (ng/mL, n: 4.6-204) & & & 1036 & 890 & 694 & 979 & 1230 & 780 & 634 \\
\hline hsTn-I (ng/L, n: 0-15.6) & & 4.7 & 5.4 & 3.7 & 1.9 & 2.2 & 2.7 & 1.2 & 1.3 \\
\hline
\end{tabular}

WBC: white blood cell, CRP: C-reactive protein, hsTn-I: high sensitivity troponin I, n: normal

\section{DISCUSSION}

Systematic reviews evaluated many studies providing clinical outcome data on the utilization of immunotherapies for the treatment of COVID-19, including CIP and IVIG administration. It seemed that immunotherapy as a supplementary therapy together with other routine cares could be an effective and safe method (6-8). However, Cochrane review by Chai et al. (9) stated that they are uncertain whether CIP is beneficial for people admitted to hospital with COVID-19.

Although there are no strict guidelines for IVIG use in COVID-19, the FDA approved the application of CIP to the severe or immediately life-threatening COVID-19 cases (10). According to the guidelines, severe disease is described as one or more of the following: Dyspnea, tachypnea $\geq 30 / \mathrm{min}$, blood oxygen saturation $\leq 93 \%$, $\mathrm{PaO}_{2} / \mathrm{FiO}_{2}<300$ and pulmonary infiltrates $>50 \%$ within 24-48 hours. Since our patient had started to have obvious dyspnea and tachypnea despite routine treatment, first dose of CIP transfusion was given on the fourth day of his admission.

IVIG might also be therapeutic option by the way of its nonspecific antiviral and immunomodulator actions. Even antibodies cross reacting with SARS-CoV-2 have been shown to be currently available IVIG preparations (11). Subgroup analysis of a research demonstrated that a high dose (>15 g/day) IVIG administration in the early phase ( $\leq 7$ days after admission) revealed significant decline in 60-day mortality in the critical cases (12). However, some reviews still conclude that the present data is inadequate to advocate the efficacy or safety of IVIG administration in the COVID-19 therapy (5).

Both CIP and IVIG could be used as a part of combined immunomodulatory therapies in COVID-19 (13-15). Successful management with plasma exchange subsequently IVIG administration in a critically ill COVID-19 case was described (16). However, in the literature, to the best of our knowledge, successful use of IVIG following CIP treatment in the same patient has not been described.

\section{CONCLUSION}

Immunotherapeutic agents as a supplementary therapy together with other routine cares in COVID-19 cases seem to be an effective and safe method. Earlier CIP transfusion followed by IVIG administration even in an adolescent with severe COVID-19 cases could be helpful to prevent mechanical ventilation and recover rapidly from COVID-19.
Informed Consent: Written informed consent was obtained from the parents of the patient for publication.

Conflict of Interest: None declared by the authors.

Financial Disclosure: None declared by the authors.

Acknowledgements: None declared by the authors.

Author Contributions: Idea/Concept: ÖÖ, BE, MCD, HS; Design: ÖÖ, BE, MCD, HS; Data Collection/Processing: ÖÖ, BE, MCD, HS; Analysis/Interpretation: ÖÖ, BE, MCD, HS; Literature Review: ÖÖ, BE, MCD, HS; Drafting/Writing: ÖÖ, BE, MCD, HS; Critical Review: ÖÖ, BE, MCD, HS.

\section{REFERENCES}

1. Özdemir Ö. Coronavirus disease 2019 (COVID-19): Diagnosis and management. Erciyes Med J. 2020;42(3):242-7.

2. Özdemir Ö, Melek Arsoy HE. Convalescent (immune) plasma therapy with all aspects: Yesterday, today and COVID-19. Erciyes Med J. 2020;42(3):252-9.

3. Duan K, Liu B, Li C, Zhang H, Yu T, Qu J, et al. Effectiveness of convalescent plasma therapy in severe COVID-19 patients. Proc Natl Acad Sci USA. 2020;117(17):9490-6.

4. Melek Arsoy HE, Özdemir Ö. Current therapeutic interventions for COVID-19. Bezmialem Science. 2020;8(Suppl 3):105-16.

5. Zhang J, Yang Y, Yang N, Ma Y, Zhou Q, Li W, et al. Effectiveness of intravenous immunoglobulin for children with severe COVID-19: a rapid review. Ann Transl Med. 2020;8(10):625.

6. Mansourabadi AH, Sadeghalvad M, MohammadiMotlagh HR, Rezaei N. The immune system as a target for therapy of SARS-CoV-2: A systematic review of the current immunotherapies for COVID-19. Life Sci. 2020;258:118185.

7. AminJafari A, Ghasemi S. The possible of immunotherapy for COVID-19: A systematic review. Int Immunopharmacol. 2020;83:106455.

8. Bakhtawar N, Usman M, Khan MMU. Convalescent plasma therapy and its effects on COVID-19 patient outcomes: A systematic review of current literature. Cureus. 2020;12(8):e9535.

9. Chai KL, Valk SJ, Piechotta V, Kimber C, Monsef I, Doree $\mathrm{C}$, et al. Convalescent plasma or hyperimmune 
immunoglobulin for people with COVID-19: a living systematic review. Cochrane Database Syst Rev. 2020;10:CD013600.

10. fda.gov [Internet]. Food and Drug Administration. Investigational COVID-19 convalescent plasma emergency INDs. [Cited: 2021 May 11]. Available from: https://www.fda.gov/vaccines-bloodbiologics/investigational-new-drug-ind-or-deviceexemption-ideprocess-cber/investigational-covid-19convalescent-plasma-emergency-inds.

11. Díez JM, Romero C, Gajardo R. Currently available intravenous immunoglobulin contains antibodies reacting against severe acute respiratory syndrome coronavirus 2 antigens. Immunotherapy. 2020;12(8):571-6.

12. Shao Z, Feng Y, Zhong L, Xie Q, Lei M, Liu Z, et al. Clinical efficacy of intravenous immunoglobulin therapy in critical ill patients with COVID-19: a multicenter retrospective cohort study. Clin Transl Immunology. 2020;9(10):e1192.
13. Abdolahi N, Kaheh E, Golsha R, Khodabakhshi B, Norouzi A, Khandashpoor M, et al. Letter to the editor: efficacy of different methods of combination regimen administrations including dexamethasone, intravenous immunoglobulin, and interferon-beta to treat critically ill COVID-19 patients: a structured summary of a study protocol for a randomized controlled trial. Trials. 2020;21(1):549.

14. Şeker E, Özdemir Ö, Pala A. Intravenous immunoglobulin therapy in COVID-19 disease. Sakarya Med J. 2021;11(2):470-2.

15. Engin M, Özdemir Ö. Potential immunological treatments in COVID-19 patients. Duzce Med J. 2021;23(1):1-9.

16. Shi H, Zhou C, He P, Huang S, Duan Y, Wang X, et al. Successful treatment with plasma exchange followed by intravenous immunoglobulin in a critically ill patient with COVID-19. Int $\mathbf{J}$ Antimicrob Agents. 2020;56(2):105974. 